\title{
The Pro-Democracy Movement: A Lost Decade?
}

Joseph Y. S. Cheng

\section{(2) OpenEdition}

\section{Journals}

\section{Electronic version}

URL: http://journals.openedition.org/chinaperspectives/1613

DOI: 10.4000/chinaperspectives.1613

ISSN: 1996-4617

\section{Publisher}

Centre d'étude français sur la Chine contemporaine

\section{Printed version}

Date of publication: 15 April 2007

ISSN: 2070-3449

\section{Electronic reference}

Joseph Y. S. Cheng, «The Pro-Democracy Movement: A Lost Decade? », China Perspectives [Online], 2007/2 | 2007, Online since 09 August 2012, connection on 28 October 2019. URL : http:// journals.openedition.org/chinaperspectives/1613; DOI : 10.4000/chinaperspectives.1613

(c) All rights reserved 


\title{
The Pro-Democracy
}

\section{Movement: A Lost Decade?}

\author{
IOSEPH Y.S. CHENG
}

I $\mathrm{n} 2007$, the pro-democracy movement in Hong Kong is not in good shape. It appears that universal suffrage will not be implemented even in 2012. The movement has held no formal dialogue with the Chinese authorities since the establishment of the Hong Kong Special Administrative Region (HKSAR) in 1997. The Chinese leadership's apparent insecurity has been much exacerbated by the massive protest rally on 1 July 2003 and the subsequent political turmoil ${ }^{(1)}$; as a result, the Chinese authorities have become more active in containing the influence of the pro-democracy movement. In the crucial Legislative Council elections in September 2004, for example, the pro-democracy parties believed that they were competing with the state machinery directed by Beijing ${ }^{(2)}$.

On the other hand, the survival of the pro-democracy camp is guaranteed by two factors. All parties concerned realise the importance of the maintenance of the rule of law and the freedom of information flow; and Hong Kong people still value the maintenance of checks and balances and they consider that support for the pro-democracy camp in elections constitutes an important means of limiting the power of the HKSAR government. It is also interesting to note that in the Chief Executive election this year, opinion surveys consistently reflected that about two-thirds of the people in Hong Kong wanted to see competition in the election, although everyone expected Donald Tsang to win and the level of support for Alan Leong, the pro-democracy movement's candidate, stayed at $20 \%$ or so. Support for the movement in the Election Committee elections in December 2006 even surpassed expectations ${ }^{(3)}$.

Hong Kong people's values have been changing. Experiences from the decade since the territory's return to the Motherland have probably lowered people's expectations concerning economic growth, career development and increases in incomes. They expect the government to assume a more significant role in the economy. They begin to pay more attention to family issues, environmental protection, preservation of the territory's historic sites, and so on. Apparently, neither the government nor the major political parties have been able to grasp this value change; and this in turn means that people's satisfaction with the respective performances of the government and political parties has been in decline (see tables 1 and 2).
This article attempts to analyse and assess the pro-democracy movement in the decade between 1997-2007 from the perspective of people's expectations, the movement's internal dynamics, the community's changes in values, and the problems and challenges ahead.

\section{People's expectations}

According to Thomas W. P. Wong, in 1997, in selecting the most important values from the four choices of economic prosperity, social stability, personal freedom and political democracy, more than half (56\%) of respondents chose social stability, $24.7 \%$ economic prosperity, $11.1 \%$ political democracy, and $8.2 \%$ personal freedom ${ }^{(4)}$. In times of political uncertainty, it was natural that people opted for stability first. Perhaps people were already aware that Hong Kong was a mature economy and one could no longer expect rapid economic growth. However, what constituted the foundation of social stability was still not clear; and it was also likely that the perceptions of the major ingredients of social stability changed in accordance with the prevailing conditions. For example, when the economy was in bad shape and the unemployment rate was very high, people were more concerned with the economy and the job market (see table 3). In the months before July 2003, people were obviously angry with the proposed Article 23 legislation ${ }^{(5)}$ and the performance of the Tung administration (see table 1).

1. See the author's edited work, The July 1 Protest Rally: Interpreting a Historic Event, Hong Kong: City University of Hong Kong Press, 2005.

2. See the author's "Hong Kong's Democrats Stumble," Journal of Democracy, vol. 16, $\mathrm{n}^{\circ}$ 1, 2005, pp. 138-152.

3. See all the major newspapers in Hong Kong, 11 and 12 December 2006.

4. Thomas W. P. Wong, "Core Values: Revelations from Research in Hong Kong's Social Indicators (1988-2001)," in Siu-kai Lau et al. (eds), Trends and Challenges in Social Development: Experiences of Hong Kong and Taiwan (in Chinese), Hong Kong: Hong Kong Institute of Asia-Pacific Studies, The Chinese University of Hong Kong, 2006, p. 108.

5. Article 23 of the Basic Law (Hong Kong's constitution) states: "The Hong Kong Specia Administrative Region shall enact laws on its own to prohibit any act of treason, secession, sedition, subversion against the Central People's Government, or theft of state secrets, to prohibit foreign political organisations or bodies from conducting political activities in the Region, and to prohibit political organisations or bodies of the Region from establishing ties with foreign political organisations or bodies". This article was written into the draft Basic Law after the massive protest rallies in Hong Kong during the Tiananmen Incident in 1989; obviously, the Chinese authorities were concerned with a repetition of such activities. 
Table 1. People's satisfaction with the HKSAR Government (half-yearly average, 1997-2006)

\section{Survey question:}

Are you satisfied with the overall performance of the HKSAR?

\begin{tabular}{|c|c|c|c|c|c|c|c|}
\hline Month of survey & $\begin{array}{l}\text { Total } \\
\text { sample }\end{array}$ & $\begin{array}{c}\text { Very } \\
\text { satisfied }\end{array}$ & $\begin{array}{c}\text { Quite } \\
\text { satisfied }\end{array}$ & Half-half & $\begin{array}{l}\text { Not quite } \\
\text { satisfied }\end{array}$ & $\begin{array}{c}\text { Very } \\
\text { dissatisfied }\end{array}$ & $\begin{array}{c}\text { Don't } \\
\text { know/ } \\
\text { Hard to } \\
\text { say }\end{array}$ \\
\hline July - Dec., 2006 & 6,076 & $4.2 \%$ & $37.8 \%$ & $41.7 \%$ & $11.4 \%$ & $3.7 \%$ & $1.1 \%$ \\
\hline Jan. - June, 2006 & 7,113 & $5.8 \%$ & $45.7 \%$ & $36.5 \%$ & $8.5 \%$ & $2.4 \%$ & $1.1 \%$ \\
\hline July - Dec., 2005 & 6,097 & $5.2 \%$ & $44.0 \%$ & $35.7 \%$ & $9.5 \%$ & $3.1 \%$ & $2.4 \%$ \\
\hline Jan. - June, 2005 & 6,109 & $2.9 \%$ & $26.2 \%$ & $37.9 \%$ & $20.2 \%$ & $8.6 \%$ & $4.3 \%$ \\
\hline July - Dec., 2004 & 6,148 & $2.7 \%$ & $17.5 \%$ & $35.3 \%$ & $27.6 \%$ & $14.2 \%$ & $2.8 \%$ \\
\hline Jan. - June, 2004 & 6,207 & $1.9 \%$ & $13.0 \%$ & $33.1 \%$ & $30.6 \%$ & $18.1 \%$ & $3.5 \%$ \\
\hline July - Dec., 2003 & 7,364 & $1.5 \%$ & $12.2 \%$ & $26.9 \%$ & $35.3 \%$ & $21.3 \%$ & $3.0 \%$ \\
\hline Jan. - June, 2003 & 6,293 & $1.1 \%$ & $14.3 \%$ & $25.6 \%$ & $36.9 \%$ & $18.6 \%$ & $3.6 \%$ \\
\hline July - Dec., 2002 & 6,260 & $1.0 \%$ & $17.0 \%$ & $28.1 \%$ & $37.9 \%$ & $11.3 \%$ & $4.8 \%$ \\
\hline Jan. - June, 2002 & 6,217 & $1.3 \%$ & $23.7 \%$ & $31.3 \%$ & $32.8 \%$ & $6.1 \%$ & $4.9 \%$ \\
\hline July - Dec., 2001 & 6,321 & $1.0 \%$ & $19.2 \%$ & $30.9 \%$ & $33.4 \%$ & $10.5 \%$ & $5.0 \%$ \\
\hline Jan. - June, 2001 & 6,348 & $1.3 \%$ & $25.3 \%$ & $35.0 \%$ & $26.7 \%$ & $6.5 \%$ & $5.2 \%$ \\
\hline July - Dec., 2000 & 6,324 & $1.5 \%$ & $19.9 \%$ & $31.3 \%$ & $32.1 \%$ & $9.6 \%$ & $5.7 \%$ \\
\hline Jan. - June, 2000 & 4,240 & $1.6 \%$ & $22.4 \%$ & $39.1 \%$ & $22.9 \%$ & $9.0 \%$ & $5.1 \%$ \\
\hline July - Dec., 1999 & 3,205 & $1.4 \%$ & $22.8 \%$ & $39.2 \%$ & $23.6 \%$ & $8.0 \%$ & $5.0 \%$ \\
\hline Jan. - June, 1999 & 4,213 & $0.7 \%$ & $24.5 \%$ & $39.9 \%$ & $26.3 \%$ & $5.4 \%$ & $3.2 \%$ \\
\hline July - Dec., 1998 & 4,755 & $1.0 \%$ & $21.7 \%$ & $35.8 \%$ & $29.0 \%$ & $8.0 \%$ & $4.6 \%$ \\
\hline Jan. - June, 1998 & 3,744 & $0.8 \%$ & $27.4 \%$ & $38.7 \%$ & $23.0 \%$ & $4.6 \%$ & $5.5 \%$ \\
\hline July - Dec., 1997 & 3,181 & $1.9 \%$ & $40.7 \%$ & $32.7 \%$ & $13.6 \%$ & $1.9 \%$ & $9.3 \%$ \\
\hline
\end{tabular}

Source: The web site of the Public Opinion Programme of The University of Hong Kong, POP Polls: People's Satisfaction with the HKSAR Government - half-yearly average. Retrieved from http://hkupop.hku.hk/english/popexpress/sargperf/sarg/halfyr/datatables.html on 28 March 2007.

C. H. Tung in his very first policy address indicated that his administration intended to be more pro-active ${ }^{(6)}$. $\mathrm{He}$ was obviously concerned with the territory's declining international competitiveness. His housing policy of providing 85,000 units per annum was an attempt to lower the cost of accommodation which had increasingly become unaffordable for ordinary Hong Kong people; but he also perceived high real estate prices as a significant factor in pushing up Hong Kong's cost structure, making its goods and services more costly and less competitive. He placed a high priority on education as a means, again, to improve Hong Kong's international competitiveness in the long run; while his emphasis on services for the elderly reflected his concern for the demands of an ageing population and the community's rising expectations for improvements in social services.

The Tung administration was wise enough not to initiate the controversial legislative process in its first term. In response to the open promoting of the Chinese authorities, a paper addressing the implementation of Article 23 of the Basic Law was finally unveiled for public consultation in September 2002. As expected, the proposals stirred fears of a crackdown on human rights groups and the Falun Gong. The pro-democracy camp in the territory also perceived the proposals to pose a threat to civil liberties. See South China Morning Post (an English language newspaper in Hong Kong), 25 September 2002.

6. For Tung's first policy address, see http://www.policyaddress.gov.hk/pa97/ english/paindex.htm, retrieved on 28 February 2007. 
U

Table 2. Ratings of major political groups, 1998-2006.

\section{Survey question:}

Please use a scale of 0-100 to rate your extent of support to XXX, with 0 indicating absolutely not supportive, 100 indicating absolutely supportive and 50 indicating half-half. How would you rate XXX?

\begin{tabular}{lccccccccc}
\hline Yearly Average & 1998 & 1999 & $\mathbf{2 0 0 0}$ & $\mathbf{2 0 0 1}$ & $\mathbf{2 0 0 2}$ & $\mathbf{2 0 0 3}$ & $\mathbf{2 0 0 4}$ & $\mathbf{2 0 0 5}$ & $\mathbf{2 0 0 6}$ \\
\hline HKFTU & 57.2 & 55.6 & 56.6 & 57.8 & 57.9 & 52.0 & 50.8 & 52.1 & 53.3 \\
$\begin{array}{l}\text { A45 Concern Group/ } \\
\text { Civic Party* }\end{array}$ & - & - & - & - & - & - & 53.4 & 53.8 & 51.8 \\
\hline HKCTU & - & 52.2 & 54.2 & 56.7 & 56.7 & 52.8 & 52.3 & 51.3 & 51.2 \\
\hline ADPL & - & 48.6 & 50.8 & 53.8 & 55.3 & 50.1 & 49.7 & 48.6 & 49.8 \\
DAB & 51.6 & 50.5 & 50.7 & 53.3 & 53.7 & 45.3 & 42.9 & 47.0 & 49.7 \\
\hline Liberal Party & 50.2 & 48.5 & 48.3 & 50.5 & 51.7 & 49.7 & 49.1 & 48.7 & 49.3 \\
Democratic Party & 56.3 & 52.3 & 51.3 & 52.6 & 51.5 & 50.2 & 51.1 & 47.9 & 47.0 \\
\hline The Frontier & 53.7 & 50.0 & 50.4 & 50.8 & 50.9 & 48.0 & 47.1 & 45.8 & 45.6 \\
\hline HKASPDMC & - & 49.2 & 48.4 & 49.5 & 48.4 & 46.4 & 45.9 & 45.6 & 43.1 \\
\hline AFA & - & - & 37.5 & 39.8 & 39.0 & 36.8 & 37.6 & 36.6 & 35.8 \\
\hline
\end{tabular}

Notss: 1. ${ }^{*} T$ The A45 Concern Group disbanded in March 2006 to form The Civic Party.

2. HKFTU $=$ Hong Kong Federation of Trade Unions HKCTU $=$ Hong Kong Confederation of Trade Unions $A D P L=$ Hong Kong Association for Democracy and People's Livelihood

$\mathrm{DAB}=$ Democratic Alliance for the Betterment of Hong Kong (currently Democratic Alliance for the Betterment and Progress of Hong Kong since 2005)

HKASPDMC = Hong Kong Alliance in Support of Patriotic Democratic Movements of China AFA = April Fifth Action

Source: Yearly averages calculated from figures at the web site of the Public Opinion Programme of The University of Hong Kong

POP Polls: Rating of Top Ten Political Groups. Retrieved from http://hkupop.hku.hk/english/popexpress/pgrating/topten1.html on 28 February 2007.

Undeniably the sharp deterioration in the territory's economic performance since 1997 caused much misery and dissatisfaction among Hong Kong people. The average annual rate of per capita gross domestic product (GDP) growth fell from $4.5 \%$ in the period 1983-1997 to 1.9\% in 1997-2001. Almost full employment was maintained from 1985 to mid-1997 as the unemployment rate ranged from $1.3 \%$ to a peak of only $3.5 \%$. Since Hong Kong's return to China, the unemployment rate climbed from $2.1 \%$ in mid-1997 to a record high of $8.7 \%$ in mid-2003 ${ }^{(7)}$. The weakening of the Hong Kong economy, however, began much earlier. Real per capita GDP growth in Hong Kong fell from an annual average of $5.2 \%$ in the 1980 s to $3.5 \%$ in 1990-1996; and per worker GDP annual growth fell from $4.7 \%$ to $3.3 \%{ }^{(8)}$. Further, a group of economists at the Chinese University of Hong Kong observed that the total factor productivity in the manufacturing sector had been declining from 1984 to 1993; its study shows that "the manufacturing sector could produce in 1993 only $87 \%$ of the output in $1984^{(9) "}$. Access to cheap labour in the Pearl River
Delta and the huge profits it generated had weakened the local manufacturing sector's incentive to invest to raise its technological level, in contrast to the other three "little dragons of Asia". The "economic bubble" in the run-up to 1997 generated by dramatic rises in prices in the real estate market and stock market also made the economic adjustment process much more painful.

Though the Tung administration failed to solve Hong Kong's economic problems, the pro-democracy movement did not have much to offer in terms of the territory's economic development strategy either. It was not able to demon-

7. Sung Yun-wing, "Hong Kong Economy in Crisis," in Siu-kai Lau (ed), The First Tung Chee-hwa Administration, Hong Kong: The Chinese University Press, 2002, p. 123.

8. Tsang Shu-ki, "Changing Structure of Hong Kong's Economy," in Gungwu Wang and John Wong (eds), Hong Kong in China: The Challenges of Transition, Singapore: Times Academic Press, 1999, p. 108.

9. Kwong Kai-sun et al., The Impact of Relocation on Total Factor Productivity of Hong Kong Manufacturing, mimeograph, Hong Kong: Department of Economics, The Chinese University of Hong Kong, August 1997 
Table 3. Perceived problems in Hong Kong most mentioned by respondents in telephone surveys conducted by the government, 1997-2003.

\begin{tabular}{|c|c|c|c|c|c|c|c|c|c|c|c|c|c|c|c|c|c|c|c|}
\hline Problems & $\begin{array}{c}\text { Jan } \\
1997 \\
\end{array}$ & $\begin{array}{c}\text { Mar } \\
1997 \\
\end{array}$ & $\begin{array}{l}\text { May } \\
1997 \\
\end{array}$ & $\begin{array}{l}\text { July } \\
1997\end{array}$ & $\begin{array}{l}\text { Sept } \\
1997\end{array}$ & $\begin{array}{c}\text { Nov } \\
1997 \\
\end{array}$ & $\begin{array}{c}\text { Jan } \\
1998 \\
\end{array}$ & $\begin{array}{c}\text { Mar } \\
1998 \\
\end{array}$ & $\begin{array}{c}\text { May } \\
1998 \\
\end{array}$ & $\begin{array}{c}\text { July } \\
1998 \\
\end{array}$ & $\begin{array}{l}\text { Sept } \\
1998 \\
\end{array}$ & $\begin{array}{l}\text { Nov } \\
1998 \\
\end{array}$ & $\begin{array}{c}\text { Jan } \\
1999 \\
\end{array}$ & $\begin{array}{c}\text { Mar } \\
1999 \\
\end{array}$ & $\begin{array}{l}\text { May } \\
1999 \\
\end{array}$ & $\begin{array}{l}\text { July } \\
1999\end{array}$ & $\begin{array}{l}\text { Sept } \\
1999\end{array}$ & $\begin{array}{l}\text { Nov } \\
1999 \\
\end{array}$ & $\begin{array}{c}\text { Jan } \\
2000 \\
\end{array}$ \\
\hline Labour-related & $27 \%$ & $25 \%$ & $19 \%$ & $18 \%$ & $19 \%$ & $24 \%$ & $33 \%$ & $41 \%$ & $54 \%$ & $48 \%$ & $49 \%$ & $50 \%$ & $46 \%$ & $49 \%$ & $47 \%$ & $45 \%$ & $38 \%$ & $47 \%$ & $51 \%$ \\
\hline Economy-related & $18 \%$ & $12 \%$ & $7 \%$ & $9 \%$ & $12 \%$ & $29 \%$ & $52 \%$ & $44 \%$ & $48 \%$ & $66 \%$ & $60 \%$ & $57 \%$ & $61 \%$ & $54 \%$ & $38 \%$ & $43 \%$ & $51 \%$ & $42 \%$ & $42 \%$ \\
\hline Governance of HK Government-related & - & - & - & - & - & - & - & - & - & - & - & - & - & - & - & - & - & - & - \\
\hline Politics and HK future-related & - & - & - & - & $4 \%$ & $5 \%$ & $5 \%$ & $5 \%$ & $3 \%$ & $3 \%$ & - & - & - & - & - & - & $4 \%$ & $2 \%$ & $2 \%$ \\
\hline Education-related & $13 \%$ & $11 \%$ & $18 \%$ & $15 \%$ & $19 \%$ & $14 \%$ & $9 \%$ & $10 \%$ & $11 \%$ & $8 \%$ & $9 \%$ & $9 \%$ & $7 \%$ & $12 \%$ & $12 \%$ & $11 \%$ & $17 \%$ & $13 \%$ & $13 \%$ \\
\hline Housing-related & $68 \%$ & $66 \%$ & $60 \%$ & $69 \%$ & $63 \%$ & $62 \%$ & $44 \%$ & $46 \%$ & $30 \%$ & $20 \%$ & $29 \%$ & $24 \%$ & $17 \%$ & $16 \%$ & $20 \%$ & $15 \%$ & $22 \%$ & $20 \%$ & $21 \%$ \\
\hline Social welfare-related & $25 \%$ & $25 \%$ & $21 \%$ & $17 \%$ & $26 \%$ & $20 \%$ & $14 \%$ & $14 \%$ & $8 \%$ & $6 \%$ & $8 \%$ & $9 \%$ & $12 \%$ & $10 \%$ & $6 \%$ & $7 \%$ & $10 \%$ & $7 \%$ & $7 \%$ \\
\hline Transport-related & $15 \%$ & $13 \%$ & $13 \%$ & $15 \%$ & $19 \%$ & $12 \%$ & $8 \%$ & $9 \%$ & $4 \%$ & $3 \%$ & - & - & $5 \%$ & $4 \%$ & $3 \%$ & $6 \%$ & $6 \%$ & $6 \%$ & - \\
\hline Environmental protection-related & - & - & - & - & - & - & - & - & $4 \%$ & $2 \%$ & $2 \%$ & $5 \%$ & $3 \%$ & $6 \%$ & $4 \%$ & $5 \%$ & $9 \%$ & $14 \%$ & $11 \%$ \\
\hline Medical and health-related & $6 \%$ & $4 \%$ & $6 \%$ & $4 \%$ & $11 \%$ & $6 \%$ & - & - & - & - & - & - & - & - & - & - & - & - & - \\
\hline New arrivals from mainland-related & - & - & - & 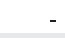 & - & - & - & - & $2 \%$ & - & $1 \%$ & $1 \%$ & $2 \%$ & $14 \%$ & - & - & - & - & - \\
\hline (Base: No. of respondents) & 1,040 & 1,045 & 1,017 & 1,099 & 1,033 & 1,033 & 1,144 & 1,099 & 1,185 & 1,272 & 1,233 & 1,296 & 1,301 & 1,247 & 1,350 & 1,219 & 1,101 & 1,237 & 1,292 \\
\hline Problems & $\begin{array}{l}\text { Mar } \\
2000\end{array}$ & $\begin{array}{l}\text { May } \\
2000\end{array}$ & $\begin{array}{l}\text { July } \\
2000\end{array}$ & $\begin{array}{l}\text { Sept } \\
2000\end{array}$ & $\begin{array}{l}\text { Nov } \\
2000\end{array}$ & $\begin{array}{l}\text { Jan } \\
2001\end{array}$ & $\begin{array}{l}\text { Mar } \\
2001\end{array}$ & $\begin{array}{l}\text { May } \\
2001\end{array}$ & $\begin{array}{c}\text { Jul } \\
2001\end{array}$ & $\begin{array}{l}\text { Sept } \\
2001\end{array}$ & $\begin{array}{l}\text { Nov } \\
2001\end{array}$ & $\begin{array}{l}\text { Jan } \\
2002\end{array}$ & $\begin{array}{l}\text { Mar } \\
2002\end{array}$ & $\begin{array}{l}\text { May } \\
2002\end{array}$ & $\begin{array}{c}\text { Jul } \\
2002\end{array}$ & $\begin{array}{c}\text { Oct } \\
2002\end{array}$ & $\begin{array}{l}\text { Jan } \\
2003\end{array}$ & $\begin{array}{l}\text { May } \\
2003\end{array}$ & $\begin{array}{l}\text { Aug } \\
2003\end{array}$ \\
\hline Labour-related & $45 \%$ & $39 \%$ & $45 \%$ & $50 \%$ & $46 \%$ & $47 \%$ & $49 \%$ & $42 \%$ & $49 \%$ & $52 \%$ & $54 \%$ & $55 \%$ & $57 \%$ & $58 \%$ & $70 \%$ & $60 \%$ & $51 \%$ & $42 \%$ & $49 \%$ \\
\hline Economy-related & $40 \%$ & $34 \%$ & $38 \%$ & $38 \%$ & $42 \%$ & $46 \%$ & $42 \%$ & $47 \%$ & $44 \%$ & $55 \%$ & $52 \%$ & $48 \%$ & $52 \%$ & $44 \%$ & $43 \%$ & $36 \%$ & $40 \%$ & $46 \%$ & $41 \%$ \\
\hline Governance of HK Government-related & - & - & - & - & - & - & - & - & - & - & $2 \%$ & $2 \%$ & $3 \%$ & $3 \%$ & $2 \%$ & $5 \%$ & $11 \%$ & $22 \%$ & $14 \%$ \\
\hline Politics and HK future-related & $1 \%$ & $3 \%$ & $4 \%$ & - & - & - & - & - & - & - & $2 \%$ & $2 \%$ & $2 \%$ & $3 \%$ & $3 \%$ & $7 \%$ & $6 \%$ & $4 \%$ & $8 \%$ \\
\hline Education-related & $18 \%$ & $19 \%$ & $17 \%$ & $16 \%$ & $14 \%$ & $16 \%$ & $18 \%$ & $21 \%$ & $19 \%$ & $20 \%$ & $16 \%$ & $13 \%$ & $15 \%$ & $14 \%$ & $14 \%$ & $11 \%$ & $8 \%$ & $5 \%$ & $8 \%$ \\
\hline Housing-related & $17 \%$ & $20 \%$ & $32 \%$ & $18 \%$ & $17 \%$ & $19 \%$ & $20 \%$ & $16 \%$ & $15 \%$ & $21 \%$ & $13 \%$ & $10 \%$ & $11 \%$ & $11 \%$ & $8 \%$ & $9 \%$ & $7 \%$ & $4 \%$ & $7 \%$ \\
\hline Social welfare-related & $11 \%$ & $10 \%$ & $4 \%$ & $6 \%$ & $7 \%$ & $7 \%$ & $6 \%$ & $6 \%$ & $4 \%$ & $4 \%$ & $4 \%$ & $5 \%$ & $6 \%$ & $8 \%$ & $5 \%$ & $5 \%$ & $7 \%$ & $4 \%$ & $2 \%$ \\
\hline Transport-related & - & - & - & - & - & $4 \%$ & $4 \%$ & $3 \%$ & $4 \%$ & $2 \%$ & $4 \%$ & $2 \%$ & $3 \%$ & $2 \%$ & $3 \%$ & $5 \%$ & - & - & - \\
\hline Environmental protection-related & $9 \%$ & $26 \%$ & $9 \%$ & $6 \%$ & $10 \%$ & $10 \%$ & $7 \%$ & $9 \%$ & $8 \%$ & $4 \%$ & $3 \%$ & $4 \%$ & $4 \%$ & $4 \%$ & $3 \%$ & - & - & - & - \\
\hline Medical and health-related & - & $10 \%$ & $3 \%$ & $3 \%$ & $2 \%$ & $6 \%$ & $4 \%$ & - & - & - & - & - & - & - & - & - & - & - & - \\
\hline (Base: No. of respondents) & 1,278 & 1,268 & 1,253 & 1,154 & 1,107 & 1,118 & 1,149 & 1,157 & 1,158 & 1,128 & 1,181 & 1,152 & 1,236 & 1,237 & 1,317 & 1,424 & 1,359 & 1,447 & 1,292 \\
\hline
\end{tabular}

Source: The telephone opinion surveys were conducted by the Home Affairs Bureau of the Hong Kong Special Administrative Region (formerly the Home Affairs Branch of the Hong Kong Government) since January 1983 until August 2003 to monitor public opinion trends in respect of perceived problems in Hong Kong, Government's overall performance and expectations about the general situation of Hong Kong. The data were provided by the Home Affairs Bureau under request.

strate significant initiatives in presenting Hong Kong people with well-researched policy alternatives. It failed to perform the role of an effective and constructive opposition from the perspective of a policy platform. According to Lau Siu-kai's survey in 2001, 63.6\% of respondents indicated that the Chief Executive could not represent their respective views, and only $12.1 \%$ of respondents said he could. Similarly, $51.7 \%$ of respondents felt that the HKSAR government could not represent their respective views, and only $15.2 \%$ felt that it could. But the Democratic Party did not fare much better: $46 \%$ of respondents indicated that it could not represent their respective views, and only $13.4 \%$ said it could. The public affairs concern groups were considered most representative: only $22.1 \%$ of respondents felt they could not represent their respective views, while $38.6 \%$ indicated that they could ${ }^{(10)}$.

The Democratic Party and other pro-democracy groups often argue that they have prepared many policy discussion papers, but they have not been able to secure the attention of the government and the media. Hence they have not been able to generate discussion within the community.
Since 1997, the HKSAR government has been treating the pro-democracy movement as the opposition, and has been trying hard to limit its impact on the government's policy deliberation processes; such efforts have been supported by the media's "self-censorship" too. It has to be admitted that the media generally do not anticipate that the pro-democracy groups' policy proposals will make an impact, hence they do not have much interest in them. Nonetheless, the prodemocracy groups as the opposition have to seek ways to influence and mobilise the community, especially the groups affected by their policy proposals; but their success has often been limited. This is especially so in economic policy discussions, because the business community and the pro-business professional groups believe that their best way to influence the government is to engage in quiet lobbying efforts; contacts and dialogue with the pro-democracy groups are per-

10. See Lau Siu-kai, "Socio-economic Discontent and Political Attitudes," in Siu-kai Lau et al. (eds), Indicators of Social Development: Hong Kong 2001, Hong Kong: Hong Kong Institute of Asia-Pacific Studies, The Chinese University of Hong Kong, 2003, p. 69. 


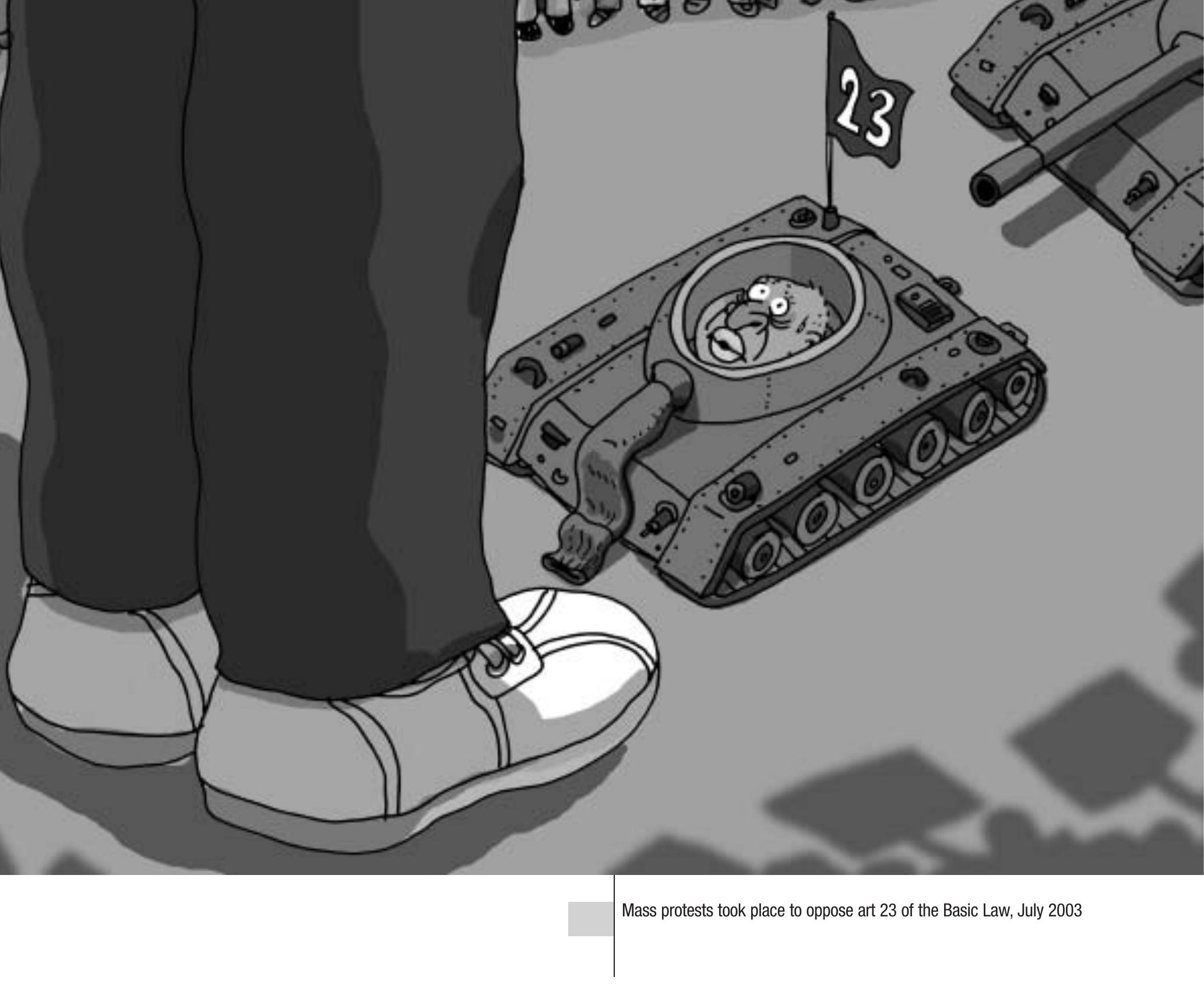

ceived to be useless and may even be counter-productive as they may offend Beijing and the HKSAR government.

In terms of the community's social policies and the change in its values, neither the government nor the political parties have been responsive. It does not appear that they have been trying hard to understand the issues. In the final years of the Tung administration and before the re-election of Donald Tsang, the HKSAR government had neither the political will nor the initiative. Yet the pro-democracy movement has not been effective in the policy areas of education, health insurance, youth work, community-building, and so on itself. Globalisation has led to a widening of the gap between rich and poor; even young university graduates have become uncertain of their middle-class status. The slowing down of economic growth, the downsizing of the civil service and most public-sector organisations, the streamlining of enterprises to enhance their profit rates, etc., mean that the younger generations of middle-class professionals and executives encounter more limited opportunities ${ }^{(I I)}$, and will probably have to seek out new sources of satisfaction. This trend may promote the further development of civil society, or may exacerbate the community's dissatisfaction and lead to protests.

Taiwan offers an interesting example. The democratisation process since the late 1980s has been accompanied by an impressive development of civic groups. Many of them engage in large-scale philanthropic activities attracting voluntary work and donations. In a few cases of natural disaster relief campaigns, their voluntary workers reached the sites ahead of government personnel. Despite the recent disillusionment with the political parties, the development of civic groups in Taiwan has not been adversely affected. Apparently, neither the political parties nor the existing civic groups in Hong Kong have been able to exploit this potential. In contrast with the 1980s, the appeal of the pro-democracy political parties for the student unions of the territory's tertiary education sector has been in decline.

11. Ohmae Kenichi, The Impact of a Rising Lower-middle Class Population in Japan: What Can We Do About It? (in Japanese), Tokyo: Kodansha, 2006. 
At the same time, the keen interest of the community in the protection of Victoria Harbour and the preservation of some historical sites including the Star Ferry Pier in Central in recent years has caught the government and all political parties by surprise. The government was complacent in view of the improved economic conditions: the unemployment rate gradually declined to $5 \%$ in mid-2006, and the economic growth rate rose from $1.8 \%$ in 2002 to $3.2 \%$ in $2003,8.6 \%$ in 2004 and $7.3 \%$ in $2005^{(12)}$. The pro-democracy political parties, on the other hand, have been perceived as insensitive to the community's changing values.

\section{Elections and political reforms}

Apparently most Hong Kong people still adopt a utilitarian attitude towards democracy. They see democracy as a means to realise practical, concrete objectives. Few Hong Kong people really practice democracy as a way of life. Since Hong Kong people treat democracy as a means to an end, they are prudent in the calculation of the costs of political participation. While they perceive democracy as an important means to guarantee their freedom, their lifestyles and their living standards which they treasure, they also consider that one's own efforts are probably more important and key in improving one's life ${ }^{(13)}$. In view of the broad trends of economic globalisation, they are now probably less confident of their individual hard work, and expect a more active role of the government.

Upon the return of the territory to China, the vast majority of Hong Kong people had, to some extent, accepted the substitution of stability and prosperity for democracy. They lowered their expectations of democracy because they realised that this was not a realistic goal, but they did value the high living standards that the territory had been offering them. Changes in such factors, however, and the mood of the community would also change, and dramatically. The massive demonstrations in response to Tiananmen in 1989 were a vivid example. On 1 July 2003, more than half a million people took to the streets to protest against the Article 23 legislation and demand democracy. People who took part in the rally felt that they were making history, and were proud of the peace and order among the protesters. The crisis attracted much international media attention, and it also became an issue high on the agenda of the Chinese leadership.

The massive protest rally on 1 July 2003 was a major boost for the morale of Hong Kong's pro-democracy movement. Opposition to the Article 23 legislation was linked to the demand for democracy, and the anger with the Tung administra- tion also highlighted the importance that democracy had. People realised that they had no part in the re-election of Tung; and despite his terrible performance, the community could not force him to step down. The pro-democracy camp understood that it could not mobilise hundreds of thousands of people to march on the streets all the time; and it therefore hoped to use the elections to send a message to the Tung administration, Beijing and the world that Hong Kong people had not forgotten the popular demand for democratisation.

The record voter turnout (44.1\%) was the most important feature of the November 2003 District Council elections (see table 4). After the 1 July 2003 demonstrations, Hong Kong people came out to vote in the local elections to express their dissatisfaction with the government and reiterate their demand for democratisation. At the beginning of 2003, most observers agreed that the pro-government Democratic Alliance for the Betterment of Hong Kong (DAB) would secure a major victory in the upcoming District Council elections. The party's confidence was reflected by the number of candidates it fielded (see table 5). The DAB, with massive political donations from the pro-Beijing business groups, had, over decades, cultivated an impressive grassroots network. Further, DAB District Councillors and candidates-in-waiting had worked hard for their constituents. They provided subsidised banquets, picnics, and package tours; they were attentive to local needs and offered services ranging from free haircuts to free medical consultations, free medicine for Severe Acute Respiratory Syndrome (SARS), etc. But the DAB's support for the Tung administration and its position on the Article 23 legislation became conspicuous political liabilities. The other pro-government parties, the Liberal Party and the Hong Kong Progressive Alliance, suffered only minor losses (see table 5).

The Democratic Party reversed its decline of recent years and in 2003 gained nine more seats to reach 95 . The party certainly benefited from the public's dissatisfaction with the Tung administration, the associated anger with the DAB, and the upsurge in demand for democracy in the community, symbolised by the 1 July protest rally. The Democratic Party fielded 120 candidates, in comparison with DAB's 206, demonstrating its earlier appreciation of the need to consolidate. The relatively large number of District Councillors is an important asset of the Democratic Party in terms

12. Hong Kong Statistics: Understanding the Present, Planning the Future, poster released by the Census and Statistics Department, HKSAR Government, early July 2006.

13. See the author's edited work, Political Participation in Hong Kong - Theoretical Issues and Historical Legacy, Hong Kong: City University of Hong Kong Press, 1999. 
Table 4. Voters and voter turnout rates in District Council elections, 1982-2003.

\begin{tabular}{|c|c|c|c|c|c|}
\hline & $\begin{array}{l}\text { No. of District } \\
\text { Board/Council } \\
\text { Constituencies* }\end{array}$ & $\begin{array}{l}\text { No. of Seats } \\
\text { to be Elected }\end{array}$ & $\begin{array}{l}\text { No. of } \\
\text { Registered } \\
\text { Voters }\end{array}$ & $\begin{array}{l}\text { No. of Actual } \\
\text { Voters** }\end{array}$ & $\begin{array}{c}\text { Voter } \\
\text { Turnout } \\
\text { Rate }^{* *}\end{array}$ \\
\hline 2003 & 400 & 400 & $2,973,612$ & $1,065,363$ & $44.1 \%$ \\
\hline 1999 & 390 & 390 & $2,832,524$ & 816,503 & $35.8 \%$ \\
\hline 1994 & 346 & 346 & $2,450,372$ & 693,215 & $33.1 \%$ \\
\hline 1991 & 209 & 272 & $1,840,413$ & 423,923 & $32.5 \%$ \\
\hline 1988 & 157 & 264 & $1,610,998$ & 424,201 & $30.3 \%$ \\
\hline 1985 & 145 & 237 & $1,421,391$ & 476,558 & $37.5 \%$ \\
\hline 1982 & 122 & 132 & 899,559 & 342,764 & $38.1 \%$ \\
\hline Notes: & $\begin{array}{l}\text { * District Councils were known as } \\
{ }^{*} \text { Since some candidates were e }\end{array}$ & $\begin{array}{l}\text { fore } 1997 \text {; in the } \\
\text { some registered }\end{array}$ & $\begin{array}{l}991 \text { and be } \\
\text { thave to vo }\end{array}$ & $\begin{array}{l}\text { onstituencies returr } \\
\text { turnout rates were }\end{array}$ & $\begin{array}{l}\text { o members each } \\
\text { ed accordingly. }\end{array}$ \\
\hline
\end{tabular}

Table 5. Performance of major political parties in District Council Elections, 1994-2003.

\begin{tabular}{l|c|c|c|c|c}
\hline & $\begin{array}{c}\text { No. of } \\
\text { Candidates } \\
\text { in 2003 }\end{array}$ & $\begin{array}{c}\text { No. of } \\
\text { Seats } \\
\text { Won in } \\
2003\end{array}$ & $\begin{array}{c}\text { \% of Contested } \\
\text { Seats Won in } \\
2003\end{array}$ & $\begin{array}{c}\text { No. of Seats } \\
\text { Won in 1999 }\end{array}$ & $\begin{array}{c}\text { No. of Seats } \\
\text { Won in 1994 }\end{array}$ \\
\hline Democratic Party & 120 & 95 & 79.2 & 86 & 75 \\
\hline DAB & 206 & 62 & 30.1 & 83 & 37 \\
\hline ADPL & 37 & 25 & 67.6 & 19 & 29 \\
\hline Liberal Party & 25 & 13 & 52.0 & 15 & 18 \\
\hline The Frontier & 13 & 6 & 46.1 & 4 & 0 \\
\hline $\begin{array}{l}\text { Hong Kong Progressive } \\
\text { Alliance }\end{array}$ & 38 & 20 & 52.6 & 21 & 2 \\
\hline Notes: Percentage of contested seats won includes seats won unopposed. & & & \\
\hline Source: See the author's “The 2003 District Council Elections in Hong Kong, "Asian Survey, vol. 44, $n^{\circ}$ 5, September/October 2004, pp. 734-754.
\end{tabular}

of financial and human resources and grassroots networks. The party remains the largest and the most powerful organisation within the pro-democracy camp. Meanwhile, the other pro-democracy groups, for example, The Frontier and the Hong Kong Association for Democracy and People's Livelihood (ADPL), also performed well in the District Council elections (see table 5).
While in the 2003 District Council elections the pro-democ racy camp was seen to have won and the DAB to have suffered a serious setback, in terms of actual distribution of political force in the 18 District Councils, the pro-democracy camp enjoyed a majority in only seven councils, while progovernment members held a majority of ten, with a balanced situation in Kowloon City. This scenario further deteriorated 
Table 6. Voters and voter turnout rates in Legislative Council Elections, 1991-2004.

\begin{tabular}{|c|c|c|c|c|c|c|c|c|c|c|c|c|c|c|c|}
\hline & \multicolumn{5}{|c|}{ Geographical Constituencies } & \multicolumn{5}{|c|}{ Functional Constituencies } & \multicolumn{5}{|c|}{ Returned by Election Committee } \\
\hline & $\begin{array}{l}\text { No. of valid } \\
\text { nominations }\end{array}$ & $\begin{array}{l}\text { No. of } \\
\text { seats } \\
\text { elected }\end{array}$ & $\begin{array}{l}\text { No. of } \\
\text { Registered } \\
\text { Voters }\end{array}$ & $\begin{array}{l}\text { No. of } \\
\text { Actual } \\
\text { Voters }\end{array}$ & $\begin{array}{c}\text { Voter } \\
\text { Turnout } \\
\text { Rate } \\
(\%)\end{array}$ & $\begin{array}{l}\text { No. of valid } \\
\text { nominations }\end{array}$ & $\begin{array}{l}\text { No. of } \\
\text { seats } \\
\text { elected }\end{array}$ & $\begin{array}{l}\text { No. of } \\
\text { Registered } \\
\text { Voters }\end{array}$ & $\begin{array}{l}\text { No. of } \\
\text { Actual } \\
\text { Voters }\end{array}$ & $\begin{array}{l}\text { Voter } \\
\text { Turnout } \\
\text { Rate } \\
(\%)\end{array}$ & $\begin{array}{l}\text { No. of valid } \\
\text { nominations }\end{array}$ & $\begin{array}{l}\text { No. of } \\
\text { seats } \\
\text { elected }\end{array}$ & $\begin{array}{l}\text { No. of } \\
\text { Registered } \\
\text { Voters }\end{array}$ & $\begin{array}{l}\text { No. of } \\
\text { Actual } \\
\text { Voters }\end{array}$ & $\begin{array}{c}\text { Voter } \\
\text { Turnout } \\
\text { Rate } \\
(\%)\end{array}$ \\
\hline 2004 & 88 & 30 & $3,207,227$ & $1,784,406$ & 55.64 & 71 & 30 & 192,374 & 134,852 & 70.10 & - & - & - & - & - \\
\hline 2000 & 36 & 24 & $3,055,378$ & $1,331,080$ & 43.57 & 57 & 30 & 163,026 & 92,112 & 56.50 & 10 & 6 & 783 & 748 & 95.53 \\
\hline 1998 & 81 & 20 & $2,795,371$ & $1,489,705$ & 53.29 & 60 & 30 & 122,537 & 77,813 & 63.50 & 25 & 10 & 800 & 790 & 98.75 \\
\hline 1995 & 50 & 20 & $2,572,135^{a}$ & 920,567 & 35.79 & 70 & 30 & $1,139,835$ & 460,690 & 40.42 & 18 & 10 & 283 & 282 & 99.65 \\
\hline 1991 & 54 & 18 & $1,916,925$ & 750,476 & $39.15^{b}$ & 40 & 21 & $48,756^{c}$ & 22,919 & 47.01 & - & - & - & - & - \\
\hline
\end{tabular}

Notes: a an approximate number of registered voters calculated from the number of actual voters and the voter turnout rate.

${ }^{b}$ official record from the government. Scholars and the media suggested that this was an under-estimation and the actual turnout rate could have been as high as between $47.5 \%$ and $51.8 \%$. See, for example, Louie Kin-sheun, et al., "Who Voted in the 1991 Elections? A Socio-Demographic Profile of the Hong Kong Electorate", in Lau Siu-kai and Louie Kin-sheun (eds.), Hong Kong Tried Democracy: The 1991 Elections in Hong Kong, Hong Kong: The Chinese University of Hong Kong, 1993, pp. 1-39; and Rowena Kwok, Joan Leung and lan Scott (eds.), Votes Without Power: The Hong Kong Legislative Council Elections 1991, Hong Kong: Hong Kong University Press, 1992, p. 8

c This includes the number of registered voters for the contested constituencies only. The total number of registered voters for functional constituencies was $69,825.12$ of the 21 seats were uncontested.

as a result of the appointment system which gave the Tung administration the opportunity to reward its supporters and tip the respective political balances in favour of the government in several District Councils. After the appointments, the pro-democracy camp enjoyed a majority on only two District Councils. The pro-government majorities on the remaining 16 District Councils mean that the councils' resources will largely be denied to the pro-democracy camp. The victory for democracy therefore should be seen largely in terms of the political messages sent by the voters.

An important weakness of the pro-democracy camp was revealed by the number of candidates it fielded, about two hundred altogether in four hundred constituencies. The relatively low number of candidates was a sign of difficulties in political recruitment. Further, the strengths of the DAB discussed above remain, and again it is expected to do well in the upcoming 2007 District Council elections, an appropriate reward for its impressive services at the grassroots level. The momentum of the pro-democracy movement was only partly maintained in the September 2004 Legislative Council elections. Voter turnout reached a new high of $55.6 \%$, up a staggering $12 \%$ from that in 2000 . About 1.78 million Hong Kong people cast their votes (see table 6). In terms of the number of seats won, the pro-democracy camp did not do very well. It secured 18 in the geographical constituencies-two more than in 2000, and seven in the functional constituencies-two more than in 2000 (see table 7). The results could have been better ${ }^{(14)}$.
The pro-democracy camp was probably adversely affected by scandals, hostile media and backward campaign strategies. In terms of the share of votes won, the pro-democracy camp increased its share from $58.2 \%$ in 2000 to $60.5 \%$ in 2004 . However, this was still slightly lower than its share of $63.2 \%$ in $1998^{(15)}$. In the context of a record voter turnout and the turnout for the protests on 1 July 2003 and 1 July 2004, this was slightly disappointing because the pro-government legislators managed to retain their majority in the legislature, and the pro-democracy groups would remain in the opposition, with little impact on the legislative process. But this is exactly the design of the electoral system, which serves to deny the pro-democracy groups a majority in the legislature despite their absolute majority support in the direct elections. The Legislative Council elections in 2004 also failed to generate meaningful discussions on the significance of the elections and the related important policy issues.

The Tsang administration then offered its political reform package which suggested increasing the seats in the Legislative Council in 2008 to five directly-elected seats and five functional constituency seats. The latter would be returned by District Councillors, implying that the pro-democracy groups could hope to win two or three seats from such addi-

14. See the author's "Hong Kong's Democrats Stumble," art. cit., pp. 138-152.

15. These percentages vary a little depending on who is counted as a member of the prodemocracy camp. Experts differ to a small extent regarding the exact categorisation of one or two marginal/controversial candidates. 
Table 7. Results of major political parties in Legislative Council elections in terms of seats won, 1991-2004.

\begin{tabular}{|c|c|c|c|c|c|c|c|c|c|c|c|c|c|c|}
\hline & \multicolumn{2}{|c|}{1991} & \multicolumn{4}{|c|}{1995} & \multicolumn{3}{|c|}{1998} & \multicolumn{3}{|c|}{2000} & \multicolumn{2}{|c|}{2004} \\
\hline & GC & FC & GC & $\begin{array}{l}\text { New } \\
\text { FC }\end{array}$ & $\begin{array}{l}\text { Old } \\
\text { FC }\end{array}$ & EC & GC & FC & EC & GC & FC & EC & GC & FC \\
\hline Democratic Party & $14^{*}$ & 2 & 12 & 2 & 3 & 2 & 8 & 4 & - & 9 & 3 & - & 7 & 2 \\
\hline DAB/HKFTU & - & 1 & 2 & 2 & 2 & 2 & 5 & 3 & 3 & 6 & 4 & 1 & 9 & 3 \\
\hline ADPL & 1 & - & 2 & - & 1 & 1 & - & - & - & 1 & - & - & 1 & - \\
\hline Liberal Party & - & - & 1 & 3 & 6 & - & - & 8 & - & - & 8 & - & 2 & 8 \\
\hline The Frontier & - & - & - & - & - & - & 2 & - & - & 2 & - & - & 1 & - \\
\hline $\begin{array}{l}\text { Hong Kong Progressive } \\
\text { Alliance }\end{array}$ & - & - & - & - & - & 2 & - & 2 & 2 & 1 & 1 & 2 & - & - \\
\hline Article 45 Concern Group & - & - & - & - & - & - & - & - & - & - & - & - & 3 & 1 \\
\hline
\end{tabular}

Nolas: 1. GC = Geographical Constituencies

$\mathrm{FC}=$ Functional Constituencies

$\mathrm{EC}=$ Returned by Election Committee

2. DAB was established in 1992; Liberal Party, 1993; Democratic Party, 1994; Hong Kong Progressive Alliance, 1994;

The Frontier, 1996; and Article 45 Concern Group, 2003. The DAB and the Hong Kong Progressive Alliance merged in 2005 to form the Democratic Alliance for the Betterment and Progress of Hong Kong.

3. * The United Democrats of Hong Kong won 12 seats in the elections, while the Meeting Point won 2 seats. The two parties merged to form the present Democratic Partie in 1994.

Sources: $\quad$ Joseph Y.S. Cheng, "Hong Kong's Democrats Stumble," Journal of Democracy, vol. 16, n 1, 2005, pp. 138-152; Hsin-chi Kuan et al. (eds), The 1995 Legislative Council Elections in Hong Kong, Hong Kong: The Chinese University of Hong Kong, 1996, p. 3; Siu-kai Lau and Kin-sheun Louie (eds), Hong Kong Tried Democracy: The 1991 Elections in Hong Kong, Hong Kong: The Chinese University of Hong Kong, 1993, p. 158; Rowena Kwok et al. (eds), Votes Without Power: The Hong Kong Legislative Council Elections 1991, Hong Kong: Hong Kong University Press, 1992, pp. 5 and 212-219; and the databases of the Public Governance Programme, Lingnan University, retrieved from http://www.In.edu.hk/pgp/level2/pgpdata-f.htm on 28 February 2007

tional functional constituency seats ${ }^{(16)}$. The pro-democracy movement insisted on a timetable and a road map for the implementation of universal suffrage for the elections of the Chief Executive and the entire legislature. It refused to accept the government package as a compromise interim measure. According to the Basic Law, there should be a review of the systems for the elections after 2007, hence the reform package from the Tsang administration. Any proposals for reform, however, had to secure two-thirds majority support in the legislature first, and this provision gave the pro-democracy legislators power of veto. They were encouraged by the impressive turnout of a protest rally (250,000 according to the organisers, and 63,000 according to the police) on 4 December 2004 rejecting the reform package ${ }^{(17)}$, and managed to maintain their solidarity against the Tsang administration's attempts to win over six of them to secure the required two-thirds majority support.

The rejection of the political reform package by 24 votes was largely seen as a major setback for the Tsang adminis- tration $^{(18)}$. It was hardly a victory for the pro-democracy movement though, because public opinion was in favour of supporting the reform package. The Chinese authorities perceived this adamant position as confrontational and terminated their more friendly approach towards the prodemocracy groups initiated after the September 2004 Legislative Council elections. Pro-democracy groups had now to face a lack of electoral reforms in the foreseeable future, a considerable disappointment to their second-line leaders. By then, in the absence of any realistic chance of achieving breakthroughs, the pro-democracy movement lost its momentum.

16. For the political reform package, see the website of the Constitutional Reform Bureau of the HKSAR government at http://www.cab.gov.hk/cd/eng/past/index.htm, retrieved on 28 February 2007. See also all major newspapers on 22 December 2005.

17. South China Morning Post, 5 and 6 December 2005.

18. Ibid., 22 December 2005. 


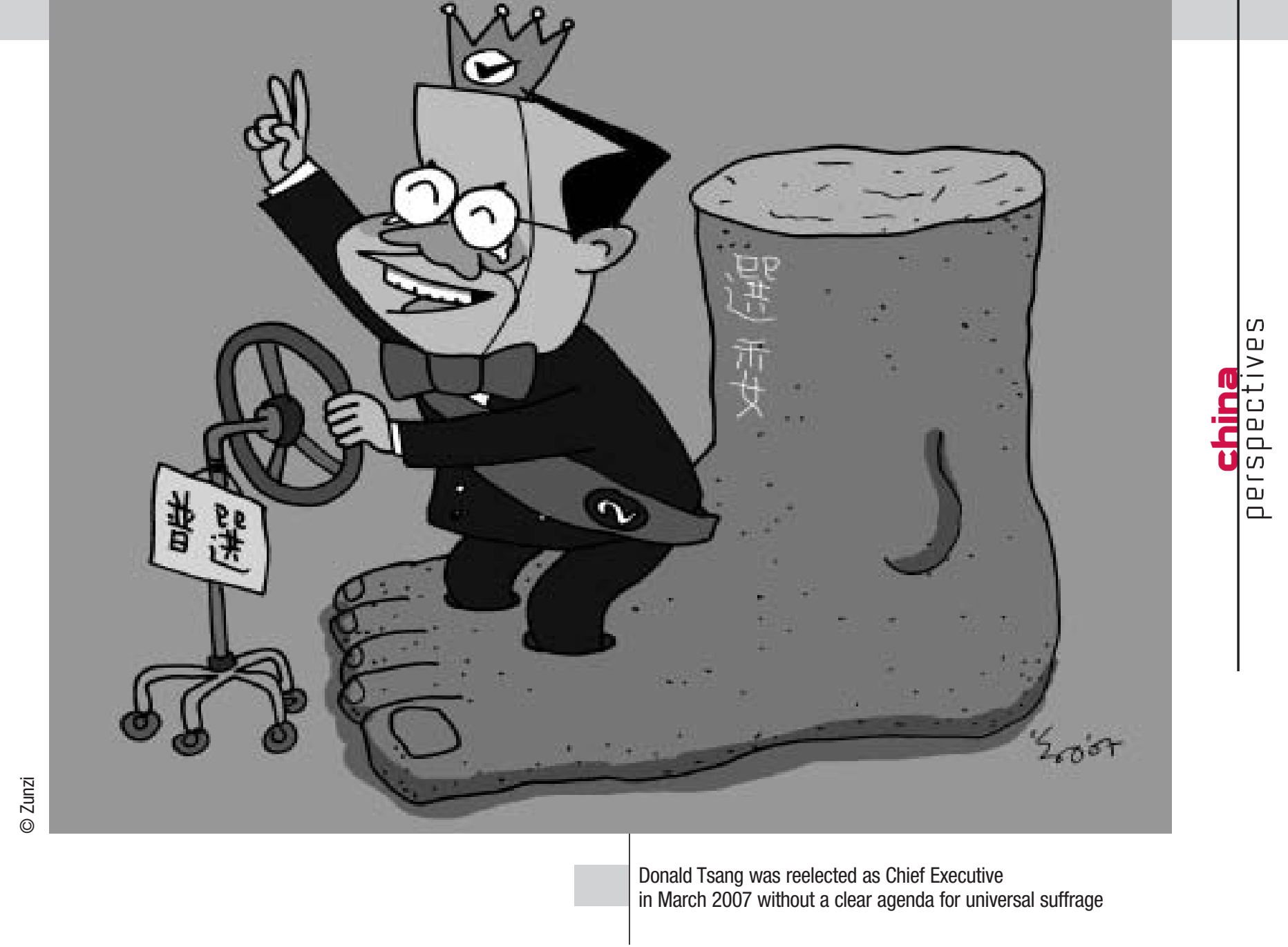

\section{Problems and challenges ahead}

For over a decade the pro-democracy movement proved effective in its electoral campaigns. In the direct elections to the legislature, it would normally secure about $60 \%$ of the electorate's support. This was mainly due to the political wisdom of a majority of Hong Kong voters who wanted to maintain effective checks and balances by returning pro-democracy candidates to the legislature to avoid the government enjoying unlimited powers. Without democratic reforms, it is difficult to imagine how the pro-democracy camp can win a majority of seats in the legislature within the existing electoral system. Hence the prodemocracy camp is not perceived as a credible alternative government, and it has not made much of an effort to achieve such an objective. It has not been able, for example, to present a shadow cabinet. Alan Leong's candidacy in the 2007 Chief Executive election represented an attempt on the part of the movement to offer a comprehensive policy platform, but the debates on it were limited.

Most Hong Kong people now accept that the issue of political reforms in the territory will be determined by the Chinese leadership, and they are reluctant to engage in confrontation with the Chinese authorities. They appreciate the fact that while there is no democracy in China, they are unlikely to be able to expect genuine democracy in Hong Kong. In the last couple of years, the new Chinese leaders have been tightening control of the media, Internet information services, dissidents, non-governmen- tal organisations, etc., and prospects for political reform in China are not promising. In the longer term, however, there is greater optimism based on the belief that economic reforms and liberties will ultimately introduce democratic reforms.

Meanwhile, the Chinese authorities have been refusing to engage in a formal dialogue with the pro-democracy groups, partly as a sanction against their role in the Tiananmen Incident and their subsequent demand to reverse the official verdict on the issue, and partly as an element of the Chinese authorities' general campaign to discredit the pro-democracy groups. There is no lack of informal contacts though, with the purpose of collecting information from activists and engaging in the usual united front tactics of winning over those who can be won over. Neither are the pro-democracy groups ready for a dialogue; and there is inadequate solidarity, trust and co-ordination among them to formulate a strategy for negotiations. The groups are notorious for not being able to keep secrets, and they fail miserably in avoiding leakage of confidential information to the media. Hence the easy way out is to stick to the bottom line inflexibly, while flexibility or tactical concessions may be easily accused of betrayal. The responses to Donald Tsang's administration's political reform package are a typical example.

Given their strong position, the Chinese authorities have no intention of negotiating. They treat the pro-democracy groups within a united front framework; in fact, they probably treat all groups in the territory within such a framework. Their basic policy is to push the pro-democracy groups to accept 
their fundamental policy position on Hong Kong. This acceptance will be rewarded, probably along the lines of their treatment of the "democratic parties" in China. But this is political suicide even for the pro-Beijing political groups in the territory. The ADPL chose to stay in the un-elected provisional legislature in 1997 instead of boycotting it like other pro-democracy groups; in the 1998 legislative elections, it lost all four seats in the Legislative Council (see table 7). The passive toeing of the Beijing line by the Hong Kong Progressive Alliance finally led to its demise in 2004; it lost all four seats in the Legislative Council elections and was forced to merge with the DAB in the following year (see table 7).

Following the logic of the united front strategy, the pro-democracy groups opposing the Beijing line most strongly would be singled out for severe sanctions for demonstrative effect. The Civic Party formally launched in March 2006 based on the Article 45 Concern Group rejected Donald Tsang's political reform package, and the business community was secretly warned against giving donations to the new party. The pro-Beijing mass media also concentrated their criticisms against the group so much so that the Democratic Party felt the pressure lift.

Beijing's united front strategy has largely failed to divide the pro-democracy groups in any significant manner, but solidarity among them has nonetheless been severely threatened. Before Hong Kong's return to China, there was substantial moral and public opinion pressure to maintain unity within the pro-democracy camp. Such pressure soon evaporated after July 1997. In the frustration of the political wilderness, differences in political orientation were exacerbated and could no longer be contained. Differences initially centred on three issues: a) the relationship with the Chinese authorities and the HKSAR government; $b$ ) whether to aggregate class interests or to articulate more clearly labour and grassroots interests; and c) whether priority should be given to effecting change by working within the legislature, or resorting to mass movements outside the political establishment.

Today, The Frontier still adopts the puritanical position of refusing to take part in the functional constituency elections to the Legislative Council. In the 2007 Chief Executive election, Alan Leong's campaign was mainly supported by the Civic Party and the Democratic Party. The Frontier, the Hong Kong Confederation of Trade Unions, and the Neighbourhood and Worker's Service Centre all refused to take part in this "small circle" election; and the newly-formed League of Social Democrats even actively opposed Alan Leong's campaign.

These differences in political orientation were even more serious within the Democratic Party, as it was easier for the pro-democracy groups to ignore their inter-group differences. The frustrations of the "young Turks" of the Democratic Party led to their challenge of the party leadership in December $1998^{(19)}$. The "young Turks" and the non-mainstream factions were opposed to efforts to improve relations with the Chinese authorities by means such as presenting candidates to compete for seats in China's National People's Congress. They were not interested in a better relationship with the HKSAR government and publicly called for Tung to resign. Regarding the party's policy platform, they warned the party leadership against opportunism in attempting to represent the interests of all classes. In turn, they were accused of trying to turn the party into a labour party and adopting a populist approach. Above all else, the "young Turks" and the non-mainstream factions appealed for a return to the grassroots to mobilise the masses instead of engaging in futile parliamentary politics.

The differences within the Democratic Party led to several waves of departure from the party on the part of the more radical members. These movements tarnished the image of the party. At the same time, the pro-democracy political parties encountered difficulties, too, in their relationship with grassroots community organisations which emerged and developed in the late 1960s and 1970s, and had been supporting prodemocracy political groups. The pro-democracy political parties certainly did help in raising issues of importance with grassroots community organisations in the legislature or with senior government officials, thus exerting pressure on the Tung administration to provide solutions. But their high profile and eagerness for publicity often resulted in failures to compromise and in delays in achieving settlements. Many grassroots community organisations worried that they might be taken for a ride, and they often preferred to act without the involvement of political parties. After all, grassroots community organisations were issue-oriented; they wanted concrete solutions to their problems. A few cases of unpleasant experiences have resulted in their alienation from the pro-democracy political parties. On the other hand, they have been eagerly courted by the pro-Beijing political groups which apparently have been making progress in their united front work.

Over the last decade, a new generation of political activists has emerged and assumed leadership in many small grassroots community organisations. These activists are less interested in the pursuit of democracy in the territory, and are

19. Ivan Chi-keung Choy, "A Coup in the Frosty Month - Counter-attack by the Non-mainstream Factions of the Democratic Party (in Chinese)," Ming Pao (a Chinese language newspaper in Hong Kong), 16 December 1998. 
Table 8. Popularity of pro-democracy

legislators, 1998-2007. ${ }^{(20)}$

The figures indicate the number of pro-democracy legislators among the top ten, top five, top three and top most popular legislative councillors being rated in the surveys.

\begin{tabular}{|c|c|c|c|c|}
\hline Month of Survey & $\begin{array}{l}\text { 히 } \\
\text { 응 }\end{array}$ & $\begin{array}{l}\stackrel{0}{i \frac{1}{0}} \\
\stackrel{0}{\circ}\end{array}$ & $\begin{array}{l}\text { dँ } \\
\text { 릉 } \\
\text { 응 }\end{array}$ & $\begin{array}{l}\text { मू } \\
\sum^{\circ} \\
\text { 응 }\end{array}$ \\
\hline January 2007 & 6 & 2 & 1 & 0 \\
\hline October 2006 & 6 & 2 & 1 & 0 \\
\hline July 2006 & 6 & 2 & 1 & 0 \\
\hline April 2006 & 6 & 2 & 1 & 0 \\
\hline January 2006 & 6 & 1 & 1 & 0 \\
\hline November 2005 & 6 & 2 & 1 & 0 \\
\hline August 2005 & 6 & 2 & 0 & 0 \\
\hline May 2005 & 6 & 3 & 1 & 0 \\
\hline February 2005 & 6 & 2 & 1 & 0 \\
\hline November 2004 & 6 & 1 & 1 & 1 \\
\hline August 2004 & 7 & 2 & 1 & 1 \\
\hline May 2004 & 6 & 2 & 1 & 1 \\
\hline February 2004 & 5 & 2 & 1 & 1 \\
\hline November 2003 & 6 & 2 & 1 & 1 \\
\hline August 2003 & 5 & 2 & 1 & 1 \\
\hline May 2003 & 5 & 2 & 1 & 0 \\
\hline February 2003 & 4 & 2 & 0 & 0 \\
\hline November 2002 & 5 & 3 & 2 & 1 \\
\hline August 2002 & 5 & 3 & 1 & 1 \\
\hline May 2002 & 5 & 2 & 1 & 0 \\
\hline February 2002 & 5 & 2 & 2 & 1 \\
\hline November 2001 & 5 & 2 & 2 & 1 \\
\hline August 2001 & 6 & 3 & 2 & 1 \\
\hline May 2001 & 5 & 2 & 2 & 0 \\
\hline February 2001 & 5 & 3 & 2 & 0 \\
\hline November 2000 & 5 & 2 & 2 & 0 \\
\hline August 2000 & 6 & 4 & 3 & 1 \\
\hline May 2000 & 6 & 4 & 3 & 1 \\
\hline March 2000 & 6 & 4 & 3 & 1 \\
\hline January 2000 & 4 & 2 & 1 & 0 \\
\hline November 1999 & 5 & 2 & 2 & 1 \\
\hline September 1999 & 7 & 4 & 2 & 1 \\
\hline July 1999 & 6 & 3 & 2 & 1 \\
\hline May 1999 & 6 & 3 & 3 & 1 \\
\hline March 1999 & 6 & 5 & 3 & 1 \\
\hline January 1999 & 6 & 5 & 3 & 1 \\
\hline November 1998 & 6 & 5 & 3 & 1 \\
\hline September 1998 & 6 & 5 & 3 & 1 \\
\hline July 1998 & 6 & 5 & 3 & 1 \\
\hline
\end{tabular}

more focused on environmental protection, community-building, gay rights, labour grievances, services for under-privileged groups, etc. They adopt more radical positions, and perceive the pro-democracy political parties as part of the political establishment. They resent the latter's concentration on parliamentary work, and criticise many pro-democracy leaders as politicians only interested in their own political careers. Their promotion of gay rights and rights for prostitutes sometimes creates difficulties for the participation of conservative religious groups.

The differences among pro-democracy political parties, within the Democratic Party, and between pro-democracy political parties and grassroots community organisations are complicated and sometimes petty as well as personal. But they have attracted considerable media attention, and resulted in damage to the reputation of all parties concerned. Moreover, these quarrels have also caused disappointment among ordinary supporters of the pro-democracy movement. It was in this context that new groups such as Power for Democracy, Hong Kong Democratic Development Network and Civil Human Rights Front emerged in early 2002. They planned to concentrate on the cause of democracy and human rights, and wanted to offer an alternative to political parties in political participation. Their emergence and development reflected the disappointment with political parties in the pro-democracy camp and the suspicions against its politicians. It was significant that these new groups were dominated by church activists and academics who were generally seen as having no political ambitions. At the time of the movement against the Article 23 legislation, these groups attempted to bring together various types of organisation in support of democracy and human rights because of the decline in appeal of the pro-democracy political parties, the suspicions against them, and the in-fighting among them and between them and the grassroots community organisations. This was not a healthy phenomenon as political parties had the resources and the most important role to play in the push for democracy in the territory. Moreover, these new groups are very limited in resources, and the pro-democracy parties are reluctant to follow their lead. The Civil Human Rights Front has become dominated by the new generation of political activists, and its relationship with the pro-democracy political parties is now problematic. Power for Democracy still assumes a useful role in the co-ordination of the pro-

20. Web site of the Public opinion programme of the University of Hong Kong, POP Polls: Rating of top Ten Legislative Councillors. Retrieved from http://hkupop.hku.hk/ english/popexpress/lcrating/topten2.html on 28 February 2007. 
democracy camp's electoral campaigns in the 2003 District Council elections, 2004 Legislative Council elections, and the 2007 District Council elections.

The pro-democracy movement at this stage and in the near future would be handicapped by three serious constraints. In comparison with the DAB and even the Liberal Party, the pro-democracy parties have not been successful in political recruitment. Businessmen and business executives are reluctant to be seen to be associated with them because of their increasingly close business ties with mainland China. The problem is more serious in terms of the generation gap. It is expected that most of their leaders will retire in the coming decade because of age (see table 8); yet the talents among the second-tier leadership are not promising. The cultivation of successors has been accorded inadequate effort and commitment.

In general, pro-democracy political parties including the Civic Party have financial problems. The Taiwan model in which enterprises offer donations to all political parties according to their relative strengths is the envy of the prodemocracy camp in Hong Kong. District Councillors affiliated to the pro-democracy political parties in Hong Kong normally have to contribute one-tenth of their salaries and allowances to pay for the functioning of their respective party headquarters, while District Councillors of the DAB are said to receive a monthly subsidy of about US\$4,000 each in support of their constituency work. This disparity illustrates the financial plight of the political opposition and explains the impressive grassroots services of the DAB.

As political parties in Hong Kong are cadre parties, they are very dependent on the media for image building and projection to maintain their appeal to the community. Hence the self-censorship of the local media is probably the most common complaint among pro-democracy legislators. Most media are in the hands of major business groups, which almost without exception have substantial business activities in mainland China. Hence media operators do not want to antagonise Beijing. Worse still, some media owners even use them as a tool to cultivate business ties with the Chinese authorities. After all, the latter fully appreciate the importance of the media in containing the pro-democracy movement; most media operators have been granted the honour of membership of the National Committee of the Chinese People's Political Consultative Conference.

Self-censorship is obviously not a problem with the international media. But after 1997, Hong Kong as a special administrative region cannot expect to attract much international media attention. In view of the importance of business ties and good relations with China, fewer and fewer West- ern governments are willing to articulate their support for democracy in Hong Kong. Pro-democracy groups in the territory are very careful and have been circumscribed in their ties with Taiwan and the United States.

Upon Hong Kong's return to China, the community's expectations of democracy had been lowered and the prodemocracy movement's development was limited by the more hostile environment-in contrast to the encouragement from the British colonial administration in its final years. The failure of the Tung administration and the provocative Article 23 legislation process brought the prodemocracy movement to a high once again. With the benefit of hindsight, the high tide revealed the restrictions imposed by the design of the electoral system, and it also showed that the Chinese authorities were ready to intervene to defend their fundamental interests in and position on Hong Kong. The dilemma for the pro-democracy movement is that while trying to secure the acceptance of the Chinese authorities would be political suicide, posing a genuine challenge would provoke a substantially higher degree of intervention. But the choice is obvious, i.e. to maintain the integrity of the movement in anticipation of democracy in China.

Survival of the pro-democracy movement, fortunately, is guaranteed by two factors. All parties concerned realise the importance of the maintenance of the rule of law and the freedom of information in the territory to ensure its functioning as an international financial centre and international business services centre. A majority of Hong Kong voters also want to guarantee a minimum of checks and balances by returning pro-democracy candidates in Legislative Council elections. Despite all the limitations in financial resources and media self-censorship, the existence of the pro-democracy movement in the territory will not be threatened for the foreseeable future.

Immediate prospects are not promising in that genuine universal suffrage will not likely be implemented by 2012; and the Chinese authorities' efforts to contain the pro-democracy movement and support the Tsang administration will continue. In the absence of an unexpected morale booster, such as the July 2003 protest, pro-democracy groups cannot realistically expect to secure substantial gains in the upcoming 2007 District Council elections and the 2008 Legislative Council elections. Better co-ordination among pro-democracy groups and more serious contributions to policy studies in areas such as education and health insurance are their immediate challenges, and they will be judged on this basis by their supporters and the media. Their past record is obviously not impressive, but there is no reason to be unduly pessimistic either. 